\title{
Shift in the Education System Stimulated by COVID-19
}

\author{
${ }^{1}$ Soulina Banerjee, ${ }^{2}$ Molla Anwarul Haque \\ ${ }^{1}$ Assistant Professor, The Heritage College Kolkata, India, ${ }^{2}$ Student, St. Xavier's College, Kolkata, \\ India. ${ }^{1}$ soulinabanerjee.25@gmail.com, ${ }^{2}$ molla_anwarul@yahoo.com
}

\begin{abstract}
A knowledge based economy is equipped with the weapon of a solution to all its problems even in the time of distress. Hence, with the augmentation of the economies there are announcements of progressive issues which in turn demand for a further augmentation in the sphere of education. India has witnessed a perpetual development in the realm of education, starting from the Vedic era of Gurukul system to the chalk and talk mode of the brick and mortar setup to the ICT enabled digitalized mechanism. The recent pandemic, namely, COVID-19 has unlocked anew demand for a digitally supplemented knowledge space. The contemporary trend tends to replace text books by e-books and resource repositories and the hefty assignments dislodged by the e-assignments which seem to be profoundly advocated by the student fraternity. Invigorated by the online mode of teaching the students band seem to favour this mechanism. The navigation through this digitalized mode of learning necessitates the need for the physical intervention of technologically sound teachers. In this framework the paper envisages to examine the factors which affect the shift from offline to online mode, coupled with analyzing the student body's reactions while accommodating the teachinglearning process during this health crisis.
\end{abstract}

Key words: Chalk and talk, Digitalized teaching learning, E-learning, Teaching learning process.

\section{INTRODUCTION}

"The use of technology coupled with bold decisions can help India leapfrog into inclusive growth and improve the quality of health and education" -Bill Gates.

India is supposed to have recorded the earliest modes of education during the Vedic era which followed the Guru Kul system of imparting knowledge, whereby students were taught under the guardianship of a guru under the open mode of class under the trees. Not only was the mode of education but the very social setup of imparting education differed from what we have today. This mode though not in the exactitude still persists. With the advent of paper and printing press there had been a radical shift on the educationalfront (Jha,N.,Shenoy,V. 2016). This phase is characterized by the brick and mortar mode whereby persisted chalk and board explanation supplemented by reference books.

Marking the sixth centennial to the previous shift we witness a digital revolution this time lead bytechnology. Now with the inclusion of ICT based education the black boards are replaced by smart boards facilitated through laptops and computers connected projectors, followed by PowerPoint mode of explanation, rather than the board and chalk based, made education fun through the inclusion of audio and visual supplements.Thus, the aforementioned shifts show a progressive nature of the transformation in the mode of imparting education through the very literacy numbers escalating from $43.6 \%$ in 1981 census to $74 \%$ in the year 2011(GOI,2011).

The changes in the educational setup has been facilitated by policy interventions by the Government of India, pertaining to the Right to Education, SarvaShikshaAbhiyan and Skill development initiatives, furthering the goal of a knowledge based economic. The Government of India's digitization stance on the educational front is noteworthy which has includes initiatives such as National Digital Library, Virtual Lab, e-ShodhSindhu, SWAYAM and FOSSEE (Rani,N. 2019). The government's leadership in paving the pathway for a digitized mode of learning and the information at the tip of the fingers of the masses has been rudimentary in this digital revolution in the education domain. In digitalization we can help India leverage the benefits of demographic dividend which it enjoys through the most up-to-date and quality e-learning solutions for the masses irrespective of their geographic lacunae.

We are in digital continuum whereby the text books are replaced by e-books and the assignments from the paper format have transformed into soft copies of e-assignments. The proliferation of digitalization in the education domain has escalated due the present health crisis, namely, COVID19. The severity of the pandemic has led to the closure of educational institutions and thus disrupting the learning process of the students, a gap in the internal assessments as 
well as public examinations. The Centre for Monitoring Indian Economy has estimated the urban unemployment rate at $24.95 \%$ (CMIE,2020) . The burden of unemployment gravitates more on the fresh graduates to come. The role of education through digital mode should cater to the educational needs of the students making them prepare for the arduous days to come. In this context the role of digitalization in the domain of education has been pivotal and the teachers of higher educational institutions have been at the forefront of this change, the online teaching methodologies. The application of information technology should be so synced in the educational reform which furthers the improvements pertaining to the learning outcomes of the students.

\section{LITERATURE REVIEW}

Jha,N.,Shenoy,V. (2016) in their paper titled "Digitization of Indian Education Process: A Hope or Hype" lays bare the continual development in the educational sphere in sync to the different components of the economy. In the study, the authors neatly distinguish the various phases in which the educational domain has matured starting from the early Guru-Shishya mode of learning to the paper based lectures to the contemporary use of technology pertaining to LCDs , touch based projectors. The study showcases the significance of a digital platform which furthers the advancement towards a digital based learning interface.

Rastogi,H. (2019) in his study "Digitalization of education in India - An analysis"advocates the significance of technology or ICT enabled educational system which stands pivotal in furthering the developmental stance of the education system in India. The author exhibits the edu-tech learning platform's potentiality of providing elucidate assistance to the students who being tech driven have well adapted to this innovative e-learning. The author furthers to explain the shift from text-books to e-books in two contrasts. Firstly, the role of e-resource in expanding the knowledge base of the learners which will facilitate them to be equipped for the dynamic setting. Contrary, the student body is exposed to a wide array of information which may not leverage the comprehended outcome. Thus, the paper showcases a decisive positive and negative impact of digital or ICT based educationon the students in particular and the society as a whole.

\section{OBJECTIVES}

1. To analyze the students reaction while adapting to online teaching-learning process during COVID-19

2. To examine the various factors affecting the shift of education from offline mode to online mode.

\section{RESEARCH METHODLOGY}

In order to address the research propositions the study was analyzed in two part namely, quantitative and qualitative research. For the quantitative analyses the data was collected through the e-questionnaire which wascirculated among the students of distinguished colleges and universities in Kolkata. The total respondents were 110 students and comprising mostly of the students belonging to the age group of 18- 23 years. For the qualitative analysis different research papers, journals newspapers and government publications were reviewed for the purpose of the study. Pertaining to the compilation of the data to provide inferential analysis the Statistical Package for the Social Sciences (SPSS) software was used.

\section{ANALYSIS AND FINDINGS}

Fig. 1 Applications used for attending online classes

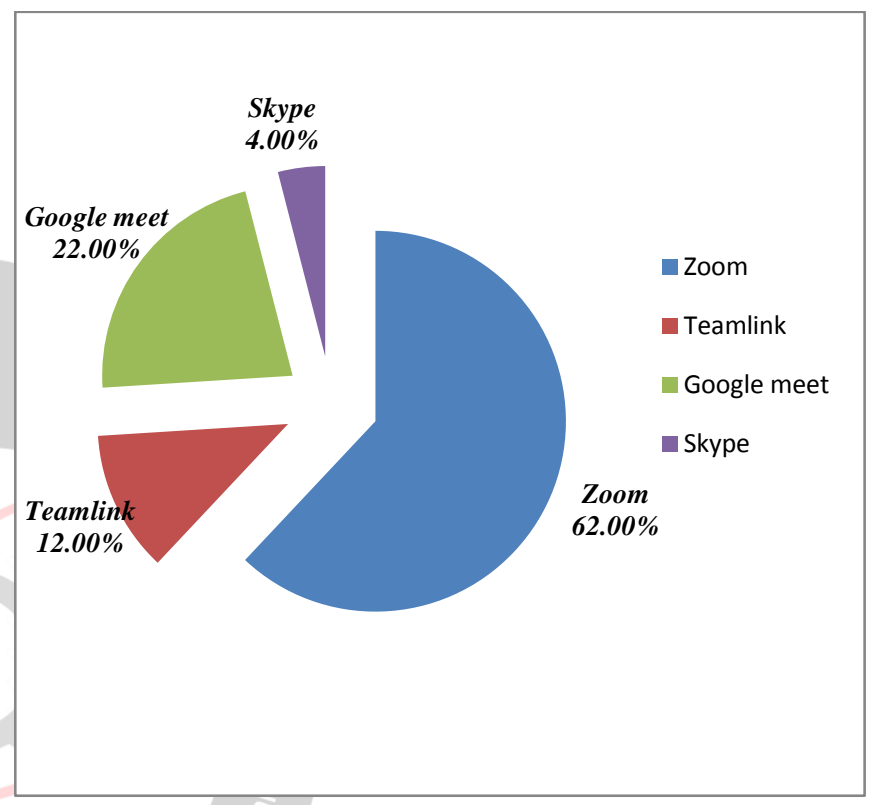

The above diagram depicts the student's escalated use of applications to attend online classes, amongst which the Zoom application finds the top favourability followed by Google meet, Teamlink and lastly, Skype.

Fig. 2 Problems while attending online classes

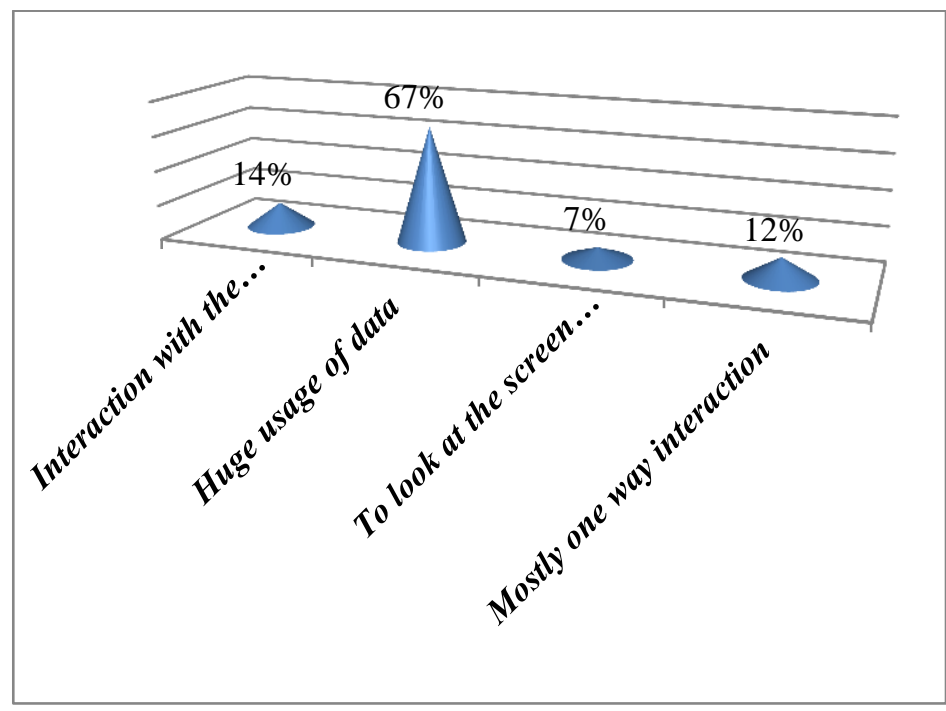

The above mentioned diagram showcases the problems faced by the student's while attending the online classes. 
The most significant amongst them being the issue of huge consumption of data followed by less interaction with the teachers succeeded by one way interaction and lastly, to look at the screen continuously for a long time.

\section{Fig. 3 Difference between offline and Online teaching}

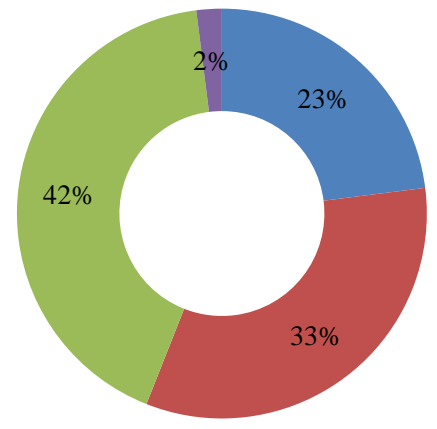

- Less interaction with the teacher

- Instant clarification of doubt after the class

Raising question in the middle of the class

- Online tests
The aforementioned diagram illustrates the significant differences in the two modes of teaching, namely, offline and online. The concern for raising question in the middle of the class marks the significant contrast in the online mode as compared to the offline, followed by another major aspect of instant clarification of doubt after the class, less interaction with the teacher and lastly, the online tests aspect.

Table 1: Factors affecting the shift of education from offline to online mode

\begin{tabular}{|c|c|c|c|c|c|}
\hline Questions & $\begin{array}{l}\text { Strongly } \\
\text { Agree }\end{array}$ & Agree & Neutral & Disagree & $\begin{array}{l}\text { Strongly } \\
\text { Disagree }\end{array}$ \\
\hline $\begin{array}{l}\text { As a student, I } \\
\text { enjoy working } \\
\text { with other } \\
\text { students in } \\
\text { groups online }\end{array}$ & $57 \%$ & $24 \%$ & $9 \%$ & $3 \%$ & $7 \%$ \\
\hline $\begin{array}{l}\text { I am willing to } \\
\text { actively } \\
\text { communicate } \\
\text { with my } \\
\text { classmates and } \\
\text { instructors } \\
\text { digitally. }\end{array}$ & $72 \%$ & $15 \%$ & $4 \%$ & $4 \%$ & $5 \%$ \\
\hline $\begin{array}{l}\text { I can ask my } \\
\text { teacher's } \\
\text { questions more } \\
\text { frequently in } \\
\text { virtual } \\
\text { classrooms }\end{array}$ & $37 \%$ & $43 \%$ & $2 \%$ & $10 \%$ & $8 \%$ \\
\hline $\begin{array}{l}\text { I feel that face- } \\
\text { to-face contact } \\
\text { with my } \\
\text { Instructor's is } \\
\text { necessary to }\end{array}$ & $43 \%$ & $39 \%$ & $1 \%$ & $14 \%$ & $3 \%$ \\
\hline
\end{tabular}

\begin{tabular}{|l|l|l|l|l|l|}
\hline learn. & & & & \\
\hline $\begin{array}{l}\text { I am motivated } \\
\text { by material } \\
\text { provided for } \\
\text { the online class }\end{array}$ & $67 \%$ & $9 \%$ & $1 \%$ & $11 \%$ & $12 \%$ \\
\hline $\begin{array}{l}\text { I can recall } \\
\text { everything } \\
\text { about the } \\
\text { previous class } \\
\text { in online mode } \\
\text { similar to that } \\
\text { of offline }\end{array}$ & $2 \%$ & $8 \%$ & $4 \%$ & $34 \%$ & $52 \%$ \\
\hline $\begin{array}{l}\text { Learning is } \\
\text { similar in both } \\
\text { online and } \\
\text { offline mode of } \\
\text { teaching. }\end{array}$ & $24 \%$ & $54 \%$ & $3 \%$ & $14 \%$ & $2 \%$ \\
\hline $\begin{array}{l}\text { I could pass a } \\
\text { course on the } \\
\text { Internet } 12 \% \\
\text { without any } \\
\text { teacher } \\
\text { assistance }\end{array}$ & $27 \%$ & $0 \%$ & $38 \%$ & $23 \%$ \\
\hline $\begin{array}{l}\text { During my } \\
\text { online class I } \\
\text { have become } \\
\text { more self- } \\
\text { disciplined and } \\
\text { find it easy to } \\
\text { set aside time } \\
\text { for reading and } \\
\text { homework }\end{array}$ & $17 \%$ & $37 \%$ & $2 \%$ & $25 \%$ & $19 \%$ \\
\hline $\begin{array}{l}\text { I feel online } \\
\text { class is better } \\
\text { than offline } \\
\text { class as it can } \\
\text { be accessed } \\
\text { easily from } \\
\text { home }\end{array}$ & $34 \%$ & $55 \%$ & $0 \%$ & $8 \%$ & \\
\hline $\begin{array}{l}\text { I } \\
\text { continue to do } \\
\text { the online } \\
\text { classes even } \\
\text { post lockdown }\end{array}$ & $8 \%$ & $22 \%$ & $7 \%$ & $53 \%$ & $10 \%$ \\
\hline
\end{tabular}

The abovementioned table explains the various factors that have influenced the students while adapting to the teaching learning process through electronic mode. The total number of student respondents was 110, out of them essentially everyone has pointed out the positive and negative facets of learning during the outbreak of the pandemic. As most of the schools and colleges are unable to conduct the normal classes in the brick and mortar setup they have shifted to the new mode of learning i.e. e-learning. Thus, the students are employing different application platforms to attended classes via online mode. The apps that are commonly used by the students are Zoom, Teamlink, Google meet etc. The students are leveraging the accessibility of the applications which formally seemed unfamiliar but the adaptability of such is high for attending online courses of the institutions. Through the responses the student's acknowledge to relish attending online classes since their appetite for easy access from the comfort of home at the same time the ease of communicating with their mentors and classmates for the purpose of assignments and other resource materials. They 
are also learning from the e-material being catered to them by their respective ementors. In the midst of all such efforts the students seem sceptical about their recallability of the previous class which stands detrimental for them in online classes. The most poignant about all of these is the striking percentage of the students unwilling to continue online classes given an option of the alternative mode of offline classes. So we can propound the adaptability of the students for online classes due to the current health crisis, post that is still a question.

\section{Table 2: Reliability Statistics}

\begin{tabular}{|l|l|}
\hline Cronbach's Alpha & No. of Items \\
\hline 0.812 & 9 \\
\hline
\end{tabular}

Table reflects that Cronbach's Alpha value for questionnaires was 0.812 which suggests good reliability. As the Cronbach's Alphas value is high now we move on with the further analysis.

Table 3: Correlation analysis

\begin{tabular}{|l|l|l|l|}
\hline \multicolumn{2}{|l|}{} & $\begin{array}{l}\text { Students } \\
\text { apprehension }\end{array}$ & $\begin{array}{l}\text { Online } \\
\text { learning } \\
\text { experience }\end{array}$ \\
\hline $\begin{array}{l}\text { Students } \\
\text { apprehension }\end{array}$ & $\begin{array}{l}\text { Pearson } \\
\text { Correlation }\end{array}$ & 1 & 0.785 \\
\cline { 2 - 4 } & Sig. (2 tailed $)$ & & 0.002 \\
\cline { 2 - 4 } & N & 110 & 110 \\
\hline \multirow{2}{*}{$\begin{array}{l}\text { Online } \\
\text { experience }\end{array}$} & $\begin{array}{l}\text { Pearson } \\
\text { Correlation }\end{array}$ & 0.785 & 1 \\
\cline { 2 - 5 } & Sig. (2 tailed) & 0.002 & 110 \\
\cline { 2 - 4 } & N & 110 & \\
\hline
\end{tabular}

Correlation is significant at 0.01 level (2 -tailed)

The aforementioned table represents Pearson correlation coefficient where the value of $r$ is 0.785 which is statistically significant at $(\mathrm{p}=0.002)$ which interprets there is positive correlation between student's apprehension during the online classes and their learning experience during the class.

\section{CONCLUSION}

It is imperative to note the role of technology in the domain of education through digital means, which stands pivotal in the overall worldly realm of educational system. It is significantto apprehend that the proponents of this aspect have not made fundamental breakthroughs for individual instructors' mode of teaching. In the aforementioned analysis we see a compelling response from the student band whereby they jewel the easy means of studying at the comfort of the home environment keep in mind the easy accessibility to the e-materials and assignments as well as being the tech-generation learners they are able to swiftly adapt to the new application platforms which facilitate the online mode of teaching. The student body rejoices with participation and questioning in the virtual educational setup displaying their keenness towards the new e-learning solutions. But it is of critical significance to analyze that students favour a physical classroom setup accompanied by online coursework completion. This points out the lacunae which still perpetuates in the virtual setup, the reason shielding this is their traditionally driven mode of classroom study i.e. chalk and talk mode. The student body finds Zoom application most accessible in attending online classes, while the issue of huge data consumption stands a problematic for them. The shift from offline to online mode has conceived the issue of raising question in the middle of the class as the most pivotal.There is a downturn concerning the recallability or retention of the online class topics which showcases a negative facet. But it is noteworthy of how the current pandemic has paved the way for moving forward to a more balanced approach towardsthe teaching and learning aspect of technology driven educational system considering the strong correlation demonstrated between the students' apprehension of the online classes and their learning experiences.

\section{RECOMMENDATIONS}

- It is fundamental in the face of the fast moving educational sector to adopt and modify the prevailing curriculum adhering system to a more holistic knowledge based system.

- In this context, the role of a judicious mix of eassignments and directing through accurate knowledge repository portals standsto materialize the conceptual utility in the practical realm.

\section{REFERENCE}

[1] Byker, Erik Jon. (2014): 'ICT in India's Elementary Schools: The Vision and Realities,' The International Education Journal: Comparative Perspectives, Vol. 13, No. 2, PP. $27-40$.

[2] Garrison, D. R., \& Cleveland-Innes, M. (2005). 'Facilitating cognitive presence in online learning: Interaction is not enough'.American Journal of Distance Education, Vol. 19, No. 3,PP. 133-148

[3] Jha, Nivedita., Shenoy, Veena. (2016): 'Digitization of Indian Education Process: A Hope or Hype,' IOSR Journal of Business and Management, Vol. 18, Issue. 10, PP. 131 139.

[4] Manoj Kumar.(2011), "Impact of the Evolution of Smart Phones in Education Technology and its Application in Technical and Professional Studies: Indian Perspective". International Journal of Managing Information Technology (IJMIT), Vol.3, No.3, PP.36-42 
[5]McBrien, J. L., Jones, P., \& Cheng, R. (2009). 'Virtual spaces: Employing a synchronous online classroom to facilitate student engagement in online learning'. International Review of Research in Open and Distance Learning, Vol. 10, No. 3, PP. 1-17.

[6] Moallem, M. (2003). 'An Interactive Online Course: A Collaborative Design Model'. Educational Technology Research andDevelopment, Vol. 5, No.4, PP. 85-103

[7] Nazarlou, Mortaza Mokhtari. (2013): 'Research on Negative Effect on E-Learning,' International Journal of Mobile Network Communications \& Telematics, Vol. 3, No.

2, PP. $11-16$

[8] Nigam, Anushree. Srivastava, Jyoti. Lakshmi, Tanushree. Vaish, Anurika. (2015): 'Digitizing Education: A Cost Benefit Analysis,' Asian Journal of Information Science and Technology, Vol. 5, no. 1, PP. 1 - 5.

[9] Rani, Neelam. (2019): 'Digitalization of higher education in India - A technological revolution'International Journal of Applied Research',2019, SP4: 282-285. ISSN Print: 2394-7500. ISSN Online: 2394-5869. Impact Factor: 5.2 .IJAR 2019; SP4: 282-285

[10] Simuforosa, Magwa. (2013): 'The Impact of Modern Technology on the Educational Attainment of Adolescents,' International Journal of Education and Research, Vol. 1, No. 9 , PP. $1-8$

\section{WEBSITE FOR REPORT}

[1] Census 2011: Office of the Registrar General \&amp; Census Commissioner, Ministry of Home Affairs, Government of India. http://censusindia.gov.in/2011-provresults/data_files/mp/07Literacy.pdf

[2] Centre for Monitoring Indian Economy: https://unemploymentinindia.cmie.com/ 